Volume 45, Number 3, p. 218-227, September, 2017

OFaculty of Veterinary Medicine, Zagazig University, 44511, Egypt

DOI: 10.21608/zvjz.2017.7945

\title{
Pharmacodynamic and Pharmacokinetic Studies on Tetracycline Hydrochloride in Rabbits
}

Elsayed A. Abdel Aziz ${ }^{1}$, Mohammed H. Khairy ${ }^{1}$, Sameh M. El-Nabtity ${ }^{1}$, Eslam E. Hamed ${ }^{2}$ and Bayan A. Saffaf ${ }^{3 *}$

${ }^{1}$ Pharmacology Department, Faculty of Veterinary Medicine, Zagazig University, 44511, Egypt

${ }^{2}$ Central Lab, Faculty of Veterinary Medicine, Zagazig University, 44511, Egypt

${ }^{3}$ Pharmacology Department, Veterinary Medicine, Hama University, Syria

Article History: Received: 19/1/2017 Received in revised form: 2/8/2017 Accepted: 1/9/2017

\begin{abstract}
Tetracycline is one of the most important groups of antibiotics that have harmful effects on the consumers, therefore the public health safety against its residues represents a significant issue. This study aimed to estimate the effect of tetracycline hydrochloride on some hematological parameters, kidneys function tests as well as liver and breast muscle enzymes with special reference to the supposed withdrawal time of this drug in different rabbits' tissues (kidney, liver and muscles), following oral dose of tetracycline using High Performance Liquid Chromatography. Tetracycline was administrated to eighteen rabbits directly into the stomach at a dose of $35 \mathrm{mg} / \mathrm{kg} \mathrm{BW}$ once daily for five successive days. Samples were collected on the $1^{\text {st }}$, $3^{\text {rd }}, 7^{\text {th }}, 14^{\text {th }}, 21^{\text {st }}$ and $28^{\text {th }}$ days after the last oral dose. The results revealed that, tetracycline caused a significant increase in the uric acid, urea, creatinine, alkaline phosphatase (ALP), aspartate aminotransferase (AST), alanine aminotransferase (ALT), creatine phosphokinase (CPK) and lactate dehydrogenase (LDH) activities with no significant changes in the hematological parameters when compared with the control group. The residues remained in the liver and kidney for 7 days, while in muscles for 3 days only after the last oral dose of the drug. In conclusion, the disturbances in the biological parameters occurred by tetracycline administration in rabbits was transient and returned to normal after 7 days of last treatment. The withdrawal time of tetracycline was 14 days from the rabbit's tissues.
\end{abstract}

Keywords: Tetracycline, Tissues, Residues, HPLC, Rabbits

\section{Introduction}

Antibiotics are widely used in animal husbandry for both preventing and treating diseases as well as promoting the growth [1]. The liver is the mostly exposed to drugs and their metabolites, but it is not the main organ for toxicity although the clinical appearance such as the side effects induced by antibiotics as microvesicular steatosis [2]. The miss use of antibiotics may result in their residues in meat and food products [3]. Observance of the withdrawal period, effective surveillance, monitoring and control on the use of veterinary drugs to prevent veterinary drug residues in animal products are recommended [4].

Tetracycline (TC) is one of the important groups of antibiotics. It is used in livestock and poultry production [5]. Tetracyclines (TCs) represent about $41 \%$ of all antibioticassociated residues, followed by $\beta$-lactams at $18 \%$ in Africa [6]. Tetracyclines have a bacteriostatic effect and used for managing a wide range of gram-positive and gramnegative bacterial infections. In addition, they are being valuable against intracellular chlamydiae, mycoplasmas, rickettsiae and protozoan parasites [7]. Tetracyclines are usually used in veterinary medicine mostly for treating gastrointestinal, respiratory and skin bacterial infections as well as systemic infections [8]. Also, tetracyclines residues cause harmful effects on consumers as allergic reactions, liver damage, yellowing of teeth and gastrointestinal disorders [9]. Therefore, this study aimed to evaluate the effect of tetracycline on liver and muscles enzymes in addition to its impact on kidney function tests and hematological parameters with special reference to its withdrawal time in different rabbit's tissues. 


\section{Material and Methods}

Thirty-six healthy male New Zealand White rabbits ranging from $2.5 \pm 0.2 \mathrm{~kg}$ body weight were divided into control and experimental group (each of 18 rabbits). The animals were housed in Experimental Research Animal Unit at the Faculty of Veterinary Medicine, Zagazig University. Rabbits were kept under good hygienic measures for 2 weeks without ant=y treatment before starting the experiment to ensure that they were free from any antibacterial drug. Feed and water were provided. The control rabbits were used for the preparation of serum, blood, blank and spiked samples for validation method. Rabbits of the experimental group were given tetracycline (Adcocycline $\AA$, Arab company for medical products - Cairo, Egypt, its molecular formula is $\mathrm{C} 22 \mathrm{H} 24 \mathrm{~N} 2 \mathrm{O} 8$ with molecular weight of $444.44 \mathrm{moL} / \mathrm{g}$ ) directly into the stomach through the feeding tube orally at a dose of 35 $\mathrm{mg} / \mathrm{kg} \mathrm{BW}$ once daily for five successive days [10]. Three rabbits were sacrificed on the $1^{\text {st }}$, $3^{\text {rd }}, 7^{\text {th }}, 14^{\text {th }}, 21^{\text {st }}$ and $28^{\text {th }}$ day after the last oral dose. Samples from kidneys, liver, muscles, blood, and serum were preserved at $-20^{\circ} \mathrm{C}$ until analysis.

\section{Preparation of samples}

Two independent blood samples per rabbit were collected from the slaughtered rabbits for hematological examinations. $1 \mathrm{~mL}$ and $2 \mathrm{~mL}$ of blood were collected in tube containing EDTA $(1 \mathrm{mg} / \mathrm{mL})$ and in a glass tube (without EDTA), respectively and allowed to coagulate in centrifuge tubes at room temperature and were centrifuged at $3000 \mathrm{rpm}$ for 15 minutes to obtain clear serum. The serum was then transferred immediately to sterile tubes and stored at $-20^{\circ} \mathrm{C}$ until biochemical assay analysis. In addition, liver, kidney and muscles samples free from surrounding tissue were collected, washed in physiological saline solution and then were stored at $-20^{\circ} \mathrm{C}$ until analyzed within 30 days from collection.

\section{Hematological parameters}

The hematological examinations included the erythrocyte count (EC), packed cell volume $(\mathrm{PCV})$, hemoglobin $(\mathrm{Hb})$, mean cell volume (MCV), mean corpuscular hemoglobin concentration (MCHC) as well as the total and differential leukocyte, using a HemScreen18-
Automated Haematology Analyser (Hospitex Diagnostics, Sesto Fiorentino, Italy) [11].

\section{Serum biochemical analysis}

Semi-automated Photometer (5010V5+, RIELEGmb H\& Co, Berlin, Germany) was used to estimate markers of serum hepatic and renal damage in freshly separated serum samples according to the manufacturer's protocol. The liver enzymes Aspartate Aminotransferase (AST) and Alanine Aminotransferase (ALT) were estimated using commercial kits [12], while Alkaline Phosphatase (ALP) was determined according to Tietz et al [13]. The enzyme activity computed directly from the absorbance values were expressed in units/L. For renal damage examination, urea was evaluated according to Coulombe and Favreau [14] and creatinine was evaluated according to Lausen [15]. In addition, muscles enzyme Creatine phosphokinase (CPK) and Lactate dehydrogenase (LDH) were evaluated [16] and [17], respectively.

\section{Sample extraction}

Frozen tissue samples were thawed and finely diced with scissors after trimming of external fat and fascia. Twenty grams of each organ to be analyzed were weighed, cut into very small pieces, grounded using sartorial mincer and then homogenized in a blender for 2 minutes, subsequently $20 \mathrm{~mL}$ of Mcllvaine buffer (Centrifuged for mixture of $1000 \mathrm{mo}$ $0.1 \mathrm{moL} / \mathrm{L}$ Citric acid and $625 \mathrm{~mL} 0.2 \mathrm{moL} / \mathrm{L}$ sodium hydrogen phosphate solution) was added. The mixture was mixed using Vortex mixer for $2 \mathrm{~min}$ and then centrifuged for 10 min (4000 g). The supernatant was taken and $20 \mu \mathrm{L}$ of the solution was injected into HPLC for analyzing.

\section{Chromatographic conditions}

The chromatographic conditions included a mobile phase of Acetonitrile and OPA acid $(0.1 \%)$ (30:70) using an isocratic method with a flow rate of $1 \mathrm{~mL} / \mathrm{min}$ at $25^{\circ} \mathrm{C}$. The separation was done on hyper sim gold C 18 $(5 \mu \mathrm{m}, 150 \times 4.6 \mathrm{~mm})$ column. Detection was performed with PDA detector set at $370 \mathrm{~nm}$ wave length. Quantification of residues in samples was obtained and calculated from the area under the curve extrapolated 
automatically by the Chromo Quest 5 software.

\section{Calibration curve}

Calibration curve was prepared by using concentrations of $0.078,0.156,0.625,1.25$, 2.5 and $5 \mathrm{ug} / \mathrm{mL}$ of tetracycline in eluent. These standards were prepared from the daily prepared stock solution and treated with 100 $\mathrm{mg}$ of tetracycline. Standard was accurately weighed and put in $100 \mathrm{~mL}$ volumetric flask, the powder was dissolved in $100 \mathrm{~mL}$ of methanol to make a stock solution of 1000 ppm $(1 \mathrm{mg} / \mathrm{mL})$. Several serial dilutions of stock solution were carried out. The retention time was 2.5 minutes.

\section{Statistical analysis}

In order to assess the influence of tetracycline on some hematological and biochemical parameters on $1^{\text {st }}, 3^{\text {rd }}, 7^{\text {th }}, 14^{\text {th }}$, $21^{\text {st }}$ and $28^{\text {th }}$ days post tetracycline administration, one-way analysis of variance (ANOVA), followed by Tukey's Honestly Significant Difference (Tukey's HSD) test as a post hoc test was used. Analysis was done using Statistical Package for Social Sciences version 22.0 (IBM Corp., Armonk, NY, USA). The results were reported as means \pm SEM (Standard Error of Mean). The value of $P<$ 0.05 was used to indicate statistical significance.

\section{Results}

The obtained results showed that the liver and muscles enzymes and kidneys functions were elevated in the serum. The treated rabbits with tetracycline hydrochloride showed an increase in the liver enzymes and kidney functions on the $1^{\text {st }}, 3^{\text {rd }}$ and $7^{\text {th }}$ days post treatment (Figurers 1,2). Also, the muscles enzymes demonstrated an increase on the $1^{\text {st }}$ and $3^{\text {rd }}$ days post oral tetracycline hydrochloride administration, while the hematological parameters displayed nonsignificant changes comparable with the control group (Table 1). Tetracycline hydrochloride distribution in the tissue was presented in Table (2). Data emphasized a widespread of the drug in the tested tissues (liver, kidneys and muscles), with the highest concentration of residues in the kidneys followed by liver then breast muscles.

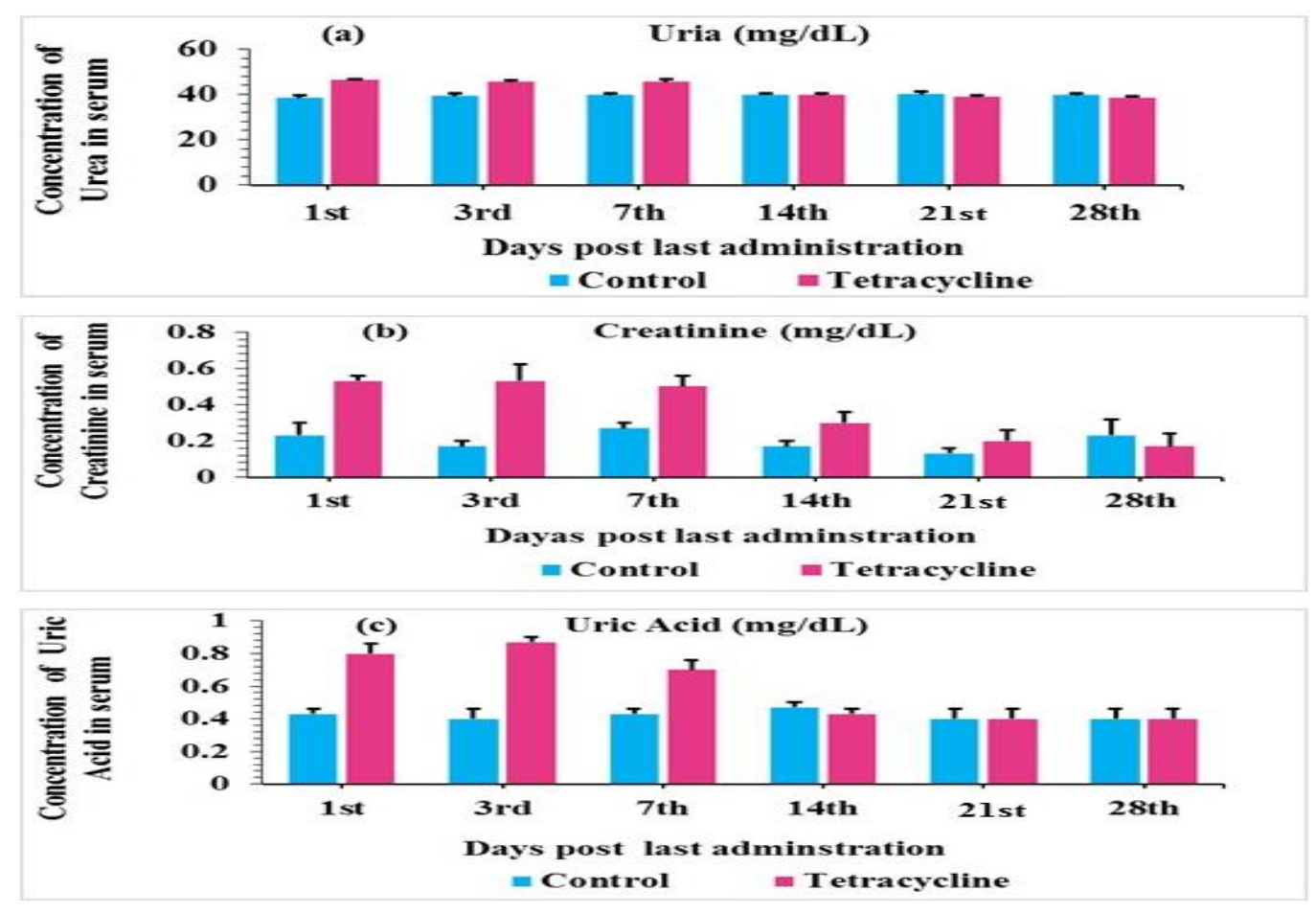

Figure 1: Different kidney function parameters' levels $(a, b, c)$ in rabbits at various intervals after treatment with tetracycline hydrochloride $(35 \mathrm{mg} \backslash \mathrm{kg} \mathrm{BW}$ once daily for 5 successive days) $(\mathrm{n}=3)$. 
The concentrations of tetracycline residues in kidneys, liver and breast muscles were $0.31 \pm 0.02, \quad 0.09 \pm 0.01$ and $0.04 \pm 0.01 \mu \mathrm{g} / \mathrm{g}$, respectively, at the $1^{\text {st }}$ day after oral administration. On the third day of tetracycline administration the residues were decreased in all investigated tissues $0.09 \pm 0.01,0.03 \pm 0.02$ and $0.01 \pm 0.01 \mu \mathrm{g} / \mathrm{g}$ in the kidney, liver and breast muscle, respectively. Moreover, on the $7^{\text {th }}$ day post treatment, the residues were not detected in the breast muscle, while on the $14^{\text {th }}$ day no residues were detected in renal and hepatic tissues.
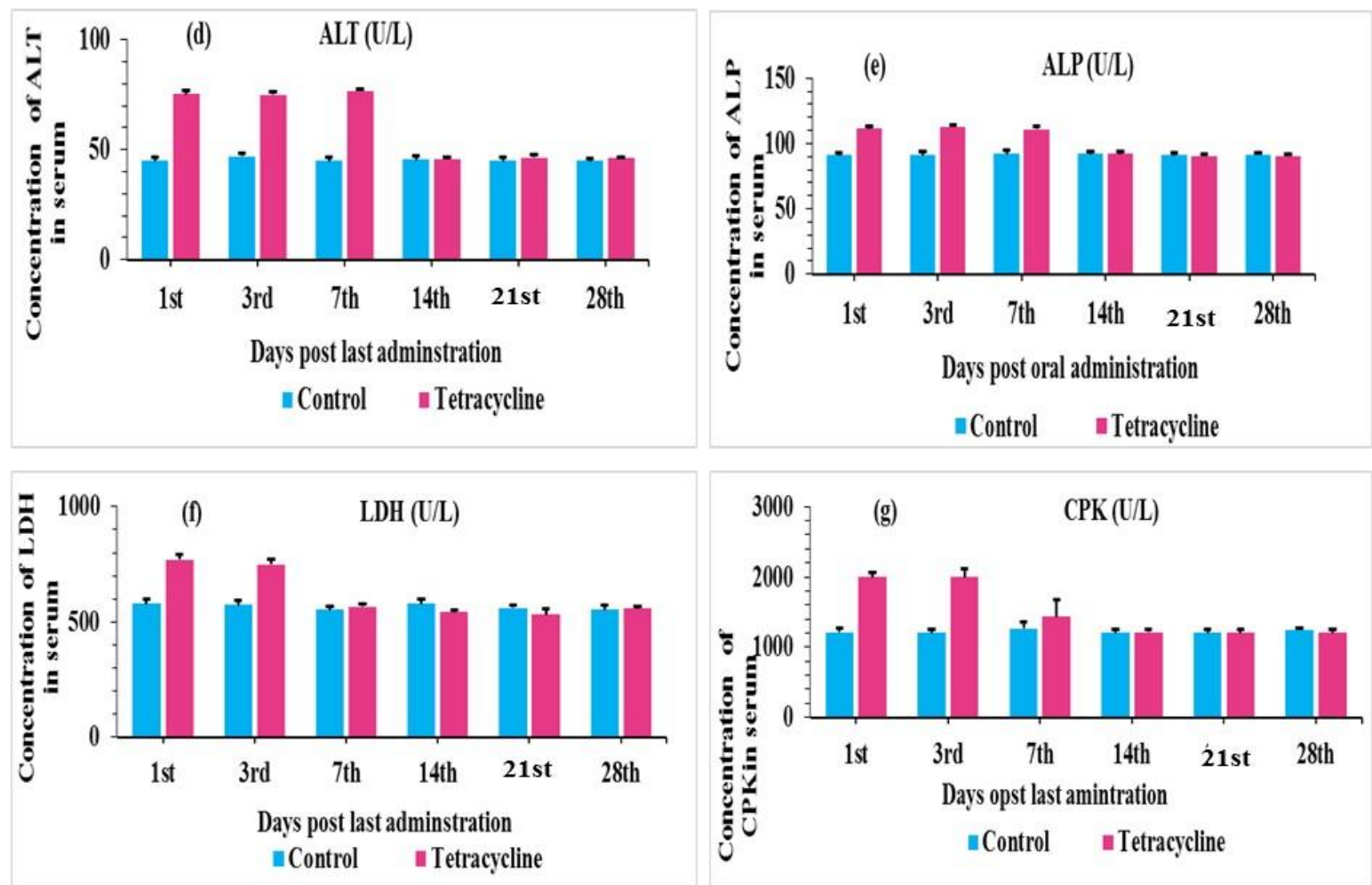

Figure 2: Liver and muscle (d,e,f,g) enzymes in serum of rabbits at various intervals after treatment with tetracycline hydrochloride (35 $\mathrm{mg} \backslash \mathrm{kg}$ BW once daily for 5 successive days) $(\mathrm{n}=3)$.

\section{Method Validation Results}

\section{System and Method of Precision}

The HPLC system is precise as the Relative Standard Deviation (RSD) of 5 determinations of Toluene standard is 0.008 . The method for tetracycline separation is precise as the Relative Standard Deviation (RSD) of 5 determinations of tetracycline test solution is 0.45 .

\section{Selectivity and specificity}

There is no interference between the tetracycline in the samples and peaks of any impurities or extracted solvents. The retention time of tetracycline is 2.5 min (Figure 3A).

\section{Standard Curve of Tetracycline}

Tetracycline standard concentrations of $0.078,0.156,0.625,1.25$ and $2.5 \mu \mathrm{g} / \mathrm{mL}$ and their corresponding peak responses (area under peak) were illustrated in Figure 3B. The calibration curve was calculated by linear regression equation method as $\mathrm{y}=41719 \mathrm{x}+279.19$ where; $\mathrm{y}$ : indicated area under peak and $\mathrm{x}$ : indicated concentrations of tetracycline. Linearity existed within range of 0.078 and $2.5 \mathrm{ug} / \mathrm{mL}$ with a correlation coefficient $\left(r^{2}=0.9999\right)$. 
Accuracy and Recovery

The percentage of recovery of tetracycline spiked samples ranged from 90-95 in kidney, muscles and liver. 
Table 1: Hematological parameter of rabbits at various intervals after administration of tetracycline hydrochloride (35mg/kg BW) orally once daily for $5 \mathrm{successive}$ days, $(\mathbf{n}=\mathbf{3})$

\begin{tabular}{|c|c|c|c|c|c|c|c|c|c|c|c|c|}
\hline & \multicolumn{12}{|c|}{ Days post treatment } \\
\hline & \multicolumn{6}{|c|}{ Control group } & \multicolumn{6}{|c|}{ Tetracycline administered group } \\
\hline & $1^{\text {st }}$ & $3^{\text {rd }}$ & $7^{\text {th }}$ & $14^{\text {th }}$ & $21^{\text {th }}$ & $28^{\text {th }}$ & $1^{\text {st }}$ & $3^{\text {rd }}$ & $7^{\text {th }}$ & $4^{\text {th }}$ & $21^{\text {th }}$ & $28^{\text {th }}$ \\
\hline${ }^{1}$ RBC.S (million/m $\mathbf{m}^{3}$ ) & $5.21 \pm 0.17$ & $5.5 \pm 0.33$ & $5.14 \pm 0.1$ & $5.29 \pm 0.17$ & $5.32 \pm 0.24$ & $4.87 \pm 0.17$ & $5.88 \pm 0.35$ & $5.35 \pm 0.04$ & $5.52 \pm 0.07$ & $5.35 \pm 0.11$ & $5.28 \pm 0.22$ & $4.83 \pm 0.77$ \\
\hline Hemoglobin (g/dL) & $12.9 \pm 0.38$ & $12.9 \pm 0.37$ & $13.5 \pm 0.39$ & $12.7 \pm 0.46$ & $3.43 \pm 0.33$ & $12.9 \pm 0.36$ & $13.2 \pm 0.35$ & $2.91 \pm 0,37$ & $12.9 \pm 0.27$ & $12.2 \pm 0.36$ & $12.8 \pm 0.32$ & $13.7 \pm 0.32$ \\
\hline${ }^{2} \mathrm{PCV}(\%)$ & $35 \pm 1.54$ & $35.9 \pm 0.85$ & $34.9 \pm 0.85$ & $34.5 \pm 1.36$ & $35.1 \pm 1.19$ & $33.1 \pm 0.71$ & $4.37 \pm 1.6$ & $36.4 \pm 0.64$ & $33.3 \pm 0.55$ & $34.8 \pm 0.91$ & $3.97 \pm 1.22$ & $32.9 \pm 1.42$ \\
\hline${ }^{3}$ M.C.V (\%) & $74.8 \pm 1.3$ & $72.9 \pm 1.7$ & $72.8 \pm 1.4$ & $74.03 \pm 1.1$ & $73.2 \pm 1.6$ & $75.1 \pm 0.7$ & $74.1 \pm 1.9$ & $74.2 \pm 1.2$ & $73.6 \pm 1.8$ & $72.8 \pm 0.8$ & $74.1 \pm 1.7$ & $73.2 \pm 1.3$ \\
\hline${ }^{4}$ M.C.H (\%) & $22.8 \pm 1.5$ & $22.9 \pm 1.1$ & $21.5 \pm 0.9$ & $22.2 \pm 1.4$ & $23.8 \pm 0.5$ & $22.2 \pm 0.6$ & $22.9 \pm 0.7$ & $22.8 \pm 0.5$ & $22.2 \pm 1.1$ & $22.4 \pm 2.9$ & $22.3 \pm 0.5$ & $22.5 \pm 0.6$ \\
\hline${ }^{5}$ M.C.H.C. (\%) & $32.2 \pm 0.6$ & $34.9 \pm 0.9$ & $31.3 \pm 0.8$ & $31.1 \pm 1.1$ & $31.9 \pm 0.4$ & $32.9 \pm 1.2$ & $31.6 \pm 0.6$ & $33.5 \pm 0.8$ & $31.0 \pm 0.6$ & $31.6 \pm 0.3$ & $31.7 \pm 0.2$ & $31.0 \pm 0.8$ \\
\hline${ }^{6} \mathrm{WBC} . S$ (million/m $\mathbf{m}^{3}$ ) & $5.5 \pm 0.5$ & $5.2 \pm 0.5$ & $5.5 \pm 0.4$ & $5.4 \pm 0.4$ & $5.4 \pm 0.3$ & $5.3 \pm 0.2$ & $5.5 \pm 0.4$ & $5.1 \pm 0.2$ & $5.8 \pm 0.2$ & $5.8 \pm 0.3$ & $5.3 \pm 0.4$ & $5.7 \pm 0.3$ \\
\hline Neutrophiles (\%) & $30.6 \pm 1.2$ & $29.3 \pm 0.6$ & $29.6 \pm 0.8$ & $27.3 \pm 1.7$ & $27.2 \pm 1.5$ & $27.1 \pm 2.1$ & $29.1 \pm 1.5$ & $28.7 \pm 1.7$ & $28.1 \pm 1.2$ & $28.1 \pm 1.1$ & $27.4 \pm 1.4$ & $28.6 \pm 1.7$ \\
\hline Lymphocytes (\%) & $65 \pm 1.5$ & $65 \pm 1.3$ & $64 \pm 1.5$ & $67 \pm 1.2$ & $66 \pm 1.6$ & $64 \pm 1.2$ & $65 \pm 2.0$ & $65 \pm 2.3$ & $66 \pm 1.5$ & $66 \pm 2.4$ & $67 \pm 2.0$ & $65 \pm 2.1$ \\
\hline Monocytes (\%) & $3.3 \pm 0.6$ & $3.3 \pm 0.3$ & $3.6 \pm 0.3$ & $3.6 \pm 0.3$ & $3.0 \pm 0.2$ & $3.0 \pm 0.2$ & $3.3 \pm 0.5$ & $3.3 \pm 0.3$ & $3.6 \pm 0.3$ & $3.3 \pm 0.3$ & $3.3 \pm 0.3$ & $3.6 \pm 0.6$ \\
\hline Eosinophel (\%) & $1.6 \pm 0.3$ & $1.6 \pm 0.3$ & $1.7 \pm 0.2$ & $1.6 \pm 0.3$ & $1.8 \pm 0.2$ & $1.5 \pm 0.3$ & $1.6 \pm 0.2$ & $1.7 \pm 0.2$ & $1.60 \pm 0.3$ & $1.6 \pm 0.1$ & $1.7 \pm 0.2$ & $1.6 \pm 0.2$ \\
\hline
\end{tabular}

${ }^{1}$ RBC.S (million $/ \mathrm{m}^{3}$ ): red blood cells; ${ }^{2} \mathrm{PCV}(\%)$ : packed cell volume; ${ }^{3} \mathrm{M} . \mathrm{C} . \mathrm{V}(\%)$ : mean cell volume; ${ }^{4} \mathrm{M} . \mathrm{C} . \mathrm{H}(\%)$ : mean corpuscular hemoglobin; ${ }^{5} \mathrm{M} . \mathrm{C} . \mathrm{H} . \mathrm{C} .(\%)$ :mean corpuscular hemoglobin concentration; ${ }^{6} \mathrm{~W}$ BC.S $\left(\operatorname{million} / \mathrm{m}^{3}\right)$ : white blood cells.

Means within the same raw carrying different superscripts were significant different at $\mathrm{P}<0.05$ based on Tukey's Honestly Significant Difference test 


\section{Discussion}

Tetracyclines are broad spectrum antibiotics, broadly used in veterinary field to treat and control a variety of bacterial infections and as growth promoters [18]. The miss use of the drugs in the veterinary field can lead to the hazard of residues in animalderived foods [1] that may cause allergic reactions and stimulate the development of resistant strains of bacteria [19,20]. The Maximum Residue Limits (MRL) for TCs according to both FAO/WHO (1999; 2004) and Canadian limit (2015) was 200, 600 and $1200 \mu \mathrm{g} / \mathrm{kg}$ for muscle, liver and kidney, respectively [21,22].
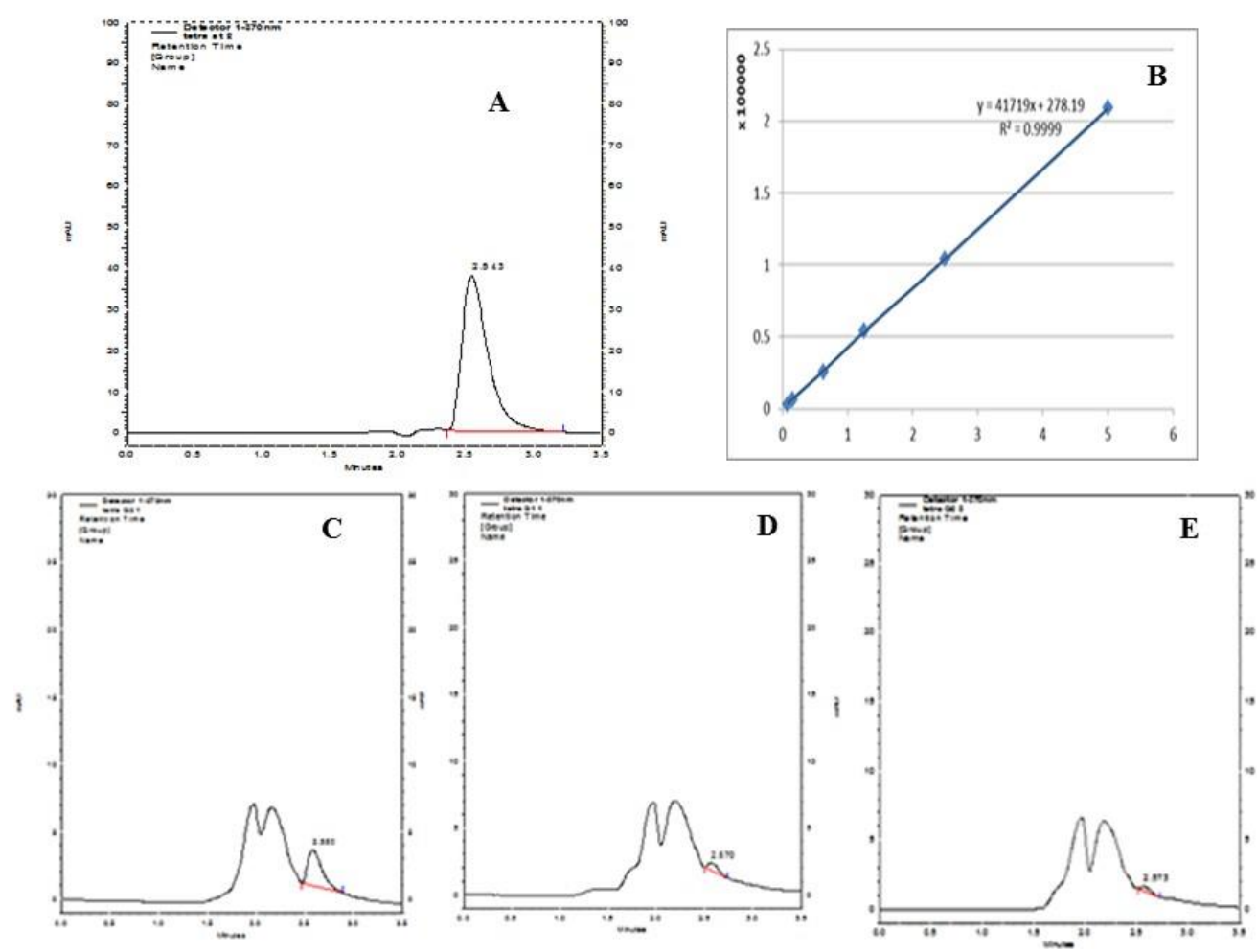

Figure 3: (A) Tetracycline standard $10 \mu \mathrm{g} / \mathrm{mL}$, (B) Standard curve of tetracycline. Liquid chromatogram of tetracycline extract $(35 \mathrm{mg} / \mathrm{kg} \mathrm{BW}$ ) orally for 5 successive day of rabbit in kidney (C), liver (D), and muscle (E) in the $1^{\text {st }}$ day post treatment.

The obtained results showed that the treatment of rabbits with tetracycline $35 \mathrm{mg} / \mathrm{kg}$ daily for 5 successive days, elicited significant increase in liver enzymes (ALT, AST and ALP) and kidney function (uric acid, urea and creatinine) on the $1^{\text {st }}, 3^{\text {rd }}$ and $7^{\text {th }}$ days post administration, respectively but on the $1^{\text {st }}$ and $3^{\text {rd }}$ days post administration only for the muscles enzymes (CPK and LDH). These results are in agreement with those obtained by Shabana et al. [23] who reported a significant elevation in the levels of ALT and AST in the serum of tetracycline-administrated rats. Increasing the level of liver enzymes in the serum may be attributed to the tetracycline induced necrotic lesions in the hepatocytes [24], and oxidative damage which might result in an enhanced release of ALT and AST into the general circulation. In addition to the raise of the AST and ALT levels refers to a reversible change of the cell membrane permeability [25]. 
Table 2: The concentration of residues in liver, kidney and muscles of rabbits at various intervals after administered of tetracycline hydrochloried $(35 \mathrm{mg} / \mathrm{kg} \mathrm{BW})$ orally once daily for 5 successive days, $\mathbf{n}=3$ (Mean \pm SE)

\begin{tabular}{|c|c|c|c|c|c|c|}
\hline \multicolumn{7}{|c|}{ The concentration of tetracycline hydrochloride residues $(\mu \mathrm{g} \backslash \mathrm{g})$} \\
\hline Organs & & post treatme & & & & \\
\hline & $1^{\text {st }}$ & $3^{\text {rd }}$ & $7^{\text {th }}$ & $14^{\text {th }}$ & $21^{\text {th }}$ & $28^{\text {th }}$ \\
\hline Liver & $0.09 \pm 0.01$ & $0.03 \pm 0.01$ & $0.02 \pm 0.01$ & ND & ND & ND \\
\hline Kidney & $0.31 \pm 0.02$ & $0.09 \pm 0.01$ & $0.02 \pm 0.01$ & ND & ND & ND \\
\hline Muscle & $0.04 \pm 0.001$ & $0.01 \pm 0.001$ & ND & ND & ND & ND \\
\hline
\end{tabular}

ND: not detected.

Regarding to the kidney function tests, our results are in agreement with those obtained by others $[26,27,28]$ who detected a significant increase in the level of urea and creatinine in the serum of tetracycline-treated rats, which may be attributed to the toxic effect of tetracycline on kidney and may have prohibited the filtration of the waste products (urea and creatinine) from the bloodstream that resulted in elevation of urea and creatinine levels in our results [29]. Effect of tetracycline on the muscles enzymes are in agreement with Laska, et al. [30] who reported that tetracycline $(0.25,1.0$ and $2.5 \mathrm{mg} / \mathrm{mL})$ caused dilation of endoplasmic reticulum and cytoplasmic blabbing at low concentration but had no effect on the cytoplasmic membrane or CPK. Cells exposed to the high concentration of tetracycline had extensive damage to the cytoplasmic membrane with completely depletion of CPK. The obtained results clearly demonstrated non-significant changes in the hematological parameters $(\mathrm{Hb}, \mathrm{PCV}, \mathrm{MCV}$, $\mathrm{MCH}$ and $\mathrm{MCHC}$ ) of the tetracycline treated rabbit that are in agreement with Shabana et al. [23] who stated that rats treated with tetracycline did not show significant changes in $\mathrm{RBC}$ count, $\mathrm{Hb}, \mathrm{PCV}, \mathrm{MCV}, \mathrm{MCH}$, $\mathrm{MCHC}$, total WBC, neutrophil, eosinophil and lymphocyte counts.

The obtained results regarding the withdrawal time of 7 days after the last dose from muscles and 14 days from the liver and kidney were in disagreement with Morshedy et al. [31] who concluded that rabbit have to delay the slaughter time till the oxytetracycline is metabolized in liver and excreted from the kidneys and this takes a withdrawal period about 3 weeks to eliminate absolutely oxytetracycline residues from rabbit muscles after treatment of $20 \mathrm{mg} / \mathrm{kg}$ body weight subcutaneously for five successive days. Villa et al. [32] referred that the withdrawal time of oxytetracycline preparation when given to rabbits by medicating water or feeding for five days at dose $80 \mathrm{mg}$ kg may be not more than 3 days. Also, Martin-jimenez et al. [33] reported that the concentrations of oxytetracycline persisted in the kidneys and muscle at the injection site for $>19$ days after oxytetracycline administered at $20 \mathrm{mg} / \mathrm{kg}$ for 3 successive days. In contrast, the withdrawal time of oxytetracycline preparation when given to rabbits by medicated water or feeding for five days at a dose of $80 \mathrm{mg} / \mathrm{kg}$ may persist not more than 3 days [32]. Such different results may be attributed to the differences in the used dose, drug metabolism and analytical procedures.

The highest concentration of tetracycline hydrochloride residues was found in kidney, liver and breast muscles, respectively, which is in agreement with Abasi et al. [34] who reported that the TC residues in triceps and gluteal muscle, diaphragm, kidney and liver samples in cattle were $176.3 \pm 46.8$, $405.3 \pm 219.6, \quad 96.8 \pm 26.9, \quad 672.4 \pm 192.0$ and $651.3 \pm 210.1 \mathrm{ng} / \mathrm{g}$, respectively. AbdelMohsein et al. [35] detected a significant difference between the level of TC in liver and that of muscle, while non-significant difference between TC level in liver and kidney. And the liver had the highest level of TC residue $(1.06 \mu \mathrm{g} / \mathrm{g})$ in comparison to other samples. The mean level of TC residues was the highest in the kidney samples that may be 
due to the major elimination pathway of tetracycline through renal excretion with approximately $60 \%$ of tetracycline administrated being excreted in urine in unchanged form [36]. Meanwhile, a higher level of tetracyclines' residue usually observed in liver and kidney rather than in the muscle, which is explaining their role in the metabolism and excretion of antibiotics, as well as to the role of the kidney in the filtration and clearance of blood from any undesirable constituents [37]. EOS had set the MRLs for oxytetracycline to be $0.2 \mathrm{ppm}$ for chicken muscles, so all the results of tetracycline residues in liver, kidney and muscles of rabbits were within the acceptable level [38].

\section{Conclusion}

In conclusion treated rabbits with tetracycline showed a significant increase in the liver and muscle enzymes and kidney function parameters. When drug eliminated from the body, the biological parameters returned to the normal, so all rabbits treated with tetracycline hydrochloride must monitor their liver and kidney function tests from time to time. On the other hand only muscles samples of rabbits at the $7^{\text {th }}$ day post treatment do not have tetracycline residues and they could be eaten safely on the $7^{\text {th }}$ day, while liver and kidney could be eaten safely on the $14^{\text {th }}$ day after treatment with tetracycline without any hazards on human health.

\section{Conflict of interest}

All the authors have no conflict of interest to declare.

\section{Acknowledgment}

The author is grateful to the staff members of Pharmacology Department, Faculty of Veterinary Medicine, Zagazig University, for their help and cooperation during the practical work.

\section{References}

[1] Cinquina, A.L.; Longo, F., Anastasi, G., Giannetti, L. and Cozzani, R. (2003): Validation of a high- performance liquid chromatography method for the determination of oxytetracycline, tetracycline, chlortetracycline and doxycycline in bovine milk and muscle. $\mathbf{J}$ ChromatogrA, 987(1): 227-233.
[2] Westphal, J.F.; Vetter, D. and Brogard, J.M. (1994): Hepatic side-effects of antibiotics. $\mathrm{J}$ Antimicrob Chemother,33(3):387-401

[3] Tajick, M.A. and Shohreh, B. (2006): Detection of Antibiotics Residue in Chicken Meat Using TLC. Int J Poult Sci, 5(7): 611-612

[4] Yunus, A. (2013): Antibiotic residue in offal (fat, liver and kidney) samples from Kumasi abattoir, Ghana. J Veterinar Sci Technolo, 4:23-24.

[5] Chopra, I. and Roperts, M. (2001): Tetracycline antibiotics: mode of action, applications, molecular biology and epidemiology of bacterial resistance. Microbiol Molecular Biolo Rev, 65(2): 232-260.

[6] Darwish, W.S.; Eldaly, E.A; El-Abbasy, M.E.; Ikenaka, Y.; Nakayama, N. and Ishizuka, M. (20013): Antibiotic residues in food: the African scenario. JPN J Vet Res, 61(Supplement): S13-S22.

[7] Eliopoulos, G. M., Eliopoulos, G. M. and Roberts, M.C. (2003): Tetracycline therapy: update. Clin Infect Dis, 36(4): 462-467.

[8] Prescot, J.F., Baggot, J.D. and Walker, R.D. (2000): Antimicrobial Therapy in Veterinary Medicine. Iowa State University Press, Ames. 277.

[9] Roberts, M.C. (1996): Tetracycline resistant determinants: mechanisms of action, regulation of expression, genetic mobility and distribution. FEMS Microbiol Rev, 19(1): 1-24.

[10] Light, R.W.; Wang, N.S.; Sassoon, C.S.; Gruer, S.E. and Vargas, F.S. (1994): Comparison of the effectiveness of tetracycline and minocycline as pleural sclerosing agents in rabbits. Chest, 106(2):577-582.

[11] Grindem, C.B. (2011): Schalm's Veterinary Hematology, 6th edition. Editors: Douglas J. Weiss, K. Jane Wardrop. Vet. Clin. Path. 40: 270

[12] Reitman, S. and Frankel, S. (1957): Determination of serum glutamic oxaloacetic transaminase and pyruvic 
transaminase by colorimetric method. Am J Clin Pathol, 28(1):57-65

[13] Tietz, N. ; Burtis, C.; Duncan, P.; Ervin, K.; Petitclerc, C. ; Rinker A; Shuey, D. and Zygowicz, E.R. (1983): A reference method for measurement of alkaline phosphatase activity in human serum. Clin Chem, 29(5): 751-761

[14] Coulombe, J and Favreau, L. (1963): A new simple semimicro method for colorimetric determination of urea. Clin Chem, 9(1):102-108.

[15] Lausen, K. (1972): Creatinine assays in the presence of protein with LKB 8600 Reaction Rate Analyser. Clin Chim Acta, 38(2): 475-476.

[16] Rosalki, S.B. (1967): An improved procedure for serum creatine phosphokinase determination. J Lab Clin Med, 69 (4):696-705

[17] Thomas, L. (1992): ed Labor und diagnose, $44^{\text {th }}$ ed Marburg: die Medizinische Verlagsgesellschaft

[18] Van Wambeke, F. (1999): Validation of HPLC method of analysis of tetracycline residues in eggs and broiler meat and its application to a feeding trial. J Food Addit Contam,16 (2): 47-56.

[19] Dayan, A.D. (1993): Allergy to antimicrobial residues in food: assessment of the risk to man. Vet Microbiol, 35(3): 213-226

[20] Hardman, J.G. and Limbird, L.E. (2007): Goodman and Gilman's the Pharmacological Basis of Therapeutics. J. New York: McGraw-Hill: 1239-1245.

[21] FAO/WHO (1999). Joint FAO/WHO food standards programme Codex Alimentarius Commission twenty-third session. Rome, Italy 28 june - 3 july 1999 . Report of the eleventh session of the codex committee on residues of veterinary drugs in foods Washington, D.C.

[22] FDA (2004). United States Food and Drug Administration. - Federal Food, Drug, and Cosmetic Act (FFDCA), as amended through December 31, 2004. Available at: http://www.fda.gov/opacom/laws/fdcact/fdctoc

[23] Shabana, M.B.; Ibrahim, H.M.; Khadre, S. E.M. and Elemam, M.G. (2012): Influence of rifampicin and tetracycline administration on some biochemical and histological parameters in albino rats. J Basic Appl Zool,65 (5): 299-308.

[24] Amin, A. and Hamza, A. A. (2005): Oxidative stress mediates drug-induced hepatotoxicity in rats: a possible role of DNA fragmentation. Toxicol, 208(3): 367375.

[25] Böcker, R.; Estler, C.J.; Müller, S; Pfandzelter, C, and Spachmüller, B. (1982): Comparative evaluation of the effects of tetracycline, rolitetracycline and doxycycline on some blood parameters related to liver function. Arzneim-Forsch, 32(3):237-241

[26] Yanardag, H.; Caner, M.; Gunes, Y. and Uygun, S. (2005): Acute hemolysis and oligoanuric acute renal failure caused by interrupted. Internet J Nephrol, 2 (1)

[27] Tasduq, S.A.; Kaiser, P.; Sharma, S.C. and Johri, R.K. (2007): Potentiation of isoniazid-induced liver toxicity by rifampicin in a combinational therapy of ant tubercular drugs (rifampicin, isoniazid and pyrazinamide) in Wistar rats. A toxicity profile study. Hepatol Res, 37(10): 845-853.

[28] Miller, C.S. and McGarityG. J. (2009): Tetracycline-induced renal failure after dental treatment. The Journal of the American Dental Association, 140 (1): 5660

[29] Bihorac, A.; Oezener, C.; Akoglu, E. and Kullu, S. (1999): Tetracycline-induced acute interstitial nephritis as a cause of acute renal failure. Nephron, 81(1):72-75.

[30] Laska, D.A.; Williams, P.D.; White, S.L, Thompson, C.A.; Hoover, D.M. (1990): In vitro correlation of ultrastructural morphology and creatine phosphokinase release in L6 skeletal muscle cells after exposure to parenteral antibiotics. In Vitro Cell Dev Biol, 26(4):393-398. 
[31] Morshedy, A.M.; Hussein, M.A. and ElGohary, A.E. (2014): Studies on oxytetracycline residues depletion in rabbit meat. Assiut Vet Med J, 60 (141): 158-166

[32] Villa, R.; Cagnardi, P.; Bacchetta, S.; Sonzogni, O.; Faustino, M. and Carli, S. (2001): Meat distripution and residue depletion of oxytetracycline in the rabbit. JWorld rabbit Science, 9(4): 159-164

[33] Martin-jimenez, T.; Craigmill, L. A. and Riviere, J.E.(1997): FARAD digest extralabel use of oxytetracycline. JAVMA, 211(1):42-45

[34] Abasi, M.M.; Rashidi, M.R.; Javadi, A.; Amirkhiz, M.A.; Mirmahdavi, S. and Zabihi, M. (2009): Levels of tetracycline residues in cattle meat, liver, and kidney from a slaughterhouse in Tabriz, Iran. Turk J Vet Anim Sci, 33(4): 345-349
[35] Abdel-Mohsein, H.S.; Mahmoud, M.A.M. and Ibrahim, A.A. (2015): Tetracycline Residues in Intensive Broiler Farms in Upper Egypt: Hazards and Risks. J World Poult Res, 5(3): 48-58

[36] Oh, Y.H. and Han, H.K. (2006): Pharmacokinetic interaction of tetracycline with non-steroidal anti-inflammatory drugs via organic anion transporters in rats. PharmacolRes, 53(1): 75-79.

[37] Lin, J.H. and Lu, A.Y. (1997): Role of Pharmacokinetics and Metabolism in Drug Discovery and Development. JPharmacol Rev, 49(4): 403-449.

[38] EOS 3692/2008: Egyptian Organization for Standardization and Quality control, maximum residue limits for vet. Drugs in foods. "chlortetracycline/oxytetracycline"

$$
\begin{aligned}
& \text { الملخص العربي } \\
& \text { دراسات فارماكوديناميكية وحركيية على التتراسيكلين هيروكلوريد في الأرانب }
\end{aligned}
$$

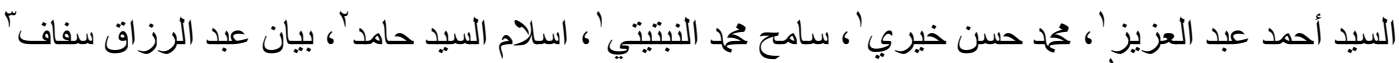

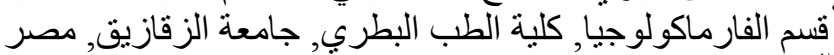

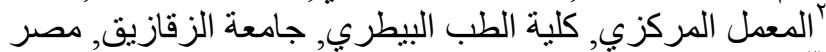

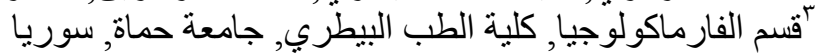

تعتبر التتر اسيكلينات إحدى أهم مجموعات المضادات الحيوية حيث تتسبب البقايا الدوائية للتتر اسكلين في إحداث آثار ضارة

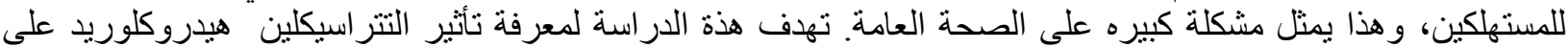

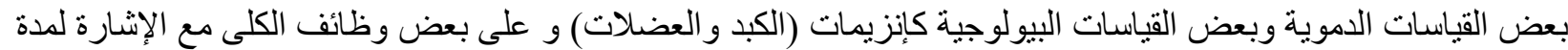

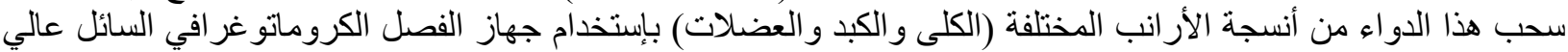

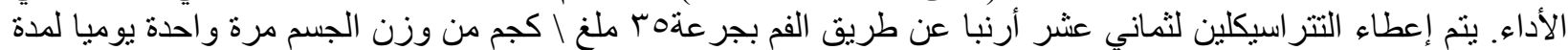

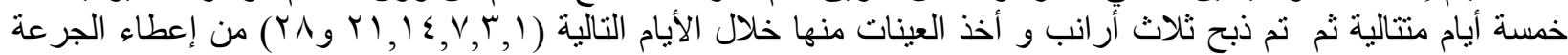

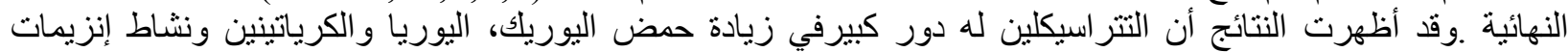
الكبد (AST,ALT ،ALP) ونشاط إنزيمات العضلات (CPK ,LDH) ولم يتم تسجيل أب تغير التيات التيات على مكونات الدم كما

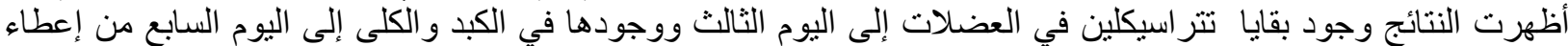

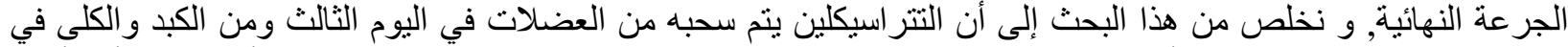

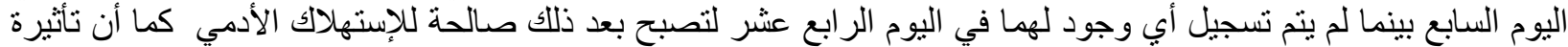

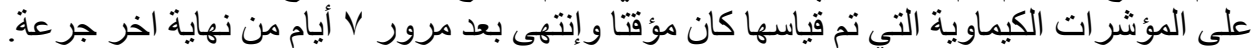

